\title{
What should we do about alcohol?
}

The end of 2015 and the beginning of 2016 produced a sheaf of news, advice and information on the health risks associated with alcohol. The Office for National Statistics published its report on the number of alcohol-related deaths in the UK. ${ }^{1}$ The UK government's Committee on Carcinogenicity of Chemicals in Food, Consumer Products and the Environment updated the cancer risks of alcohol. ${ }^{2}$ The chief medical officer for England published her updated advice on 'safe drinking'; ${ }^{3}$ the Nuffield Trust published its assessment on the effect of alcohol on hospital activity. ${ }^{4}$ A private member's bill in the Lords to reduce the permitted maximum blood alcohol level received a second reading in the House of Lords; ${ }^{5}$ and the Scottish government's initiative on minimum pricing emerged battered from the European Court of Justice, but remains potentially salvageable in the Scottish courts. ${ }^{6}$

No physicians can remain unaware of the health messages around alcohol, but some of the recent data merit emphasising. While at the end of the last decade it looked as if alcohol-related deaths in the UK were beginning to fall, the most recent (2014) figures show a slight reversal of this trend. In England more than 15,000 people a year are estimated to die an alcoholrelated death. ${ }^{4}$ Four times as many people die from alcohol as in the 1970s, and the striking regional variation remains, with the death rates from alcohol in Scotland at least 50\% higher than in the rest of the UK, as well as a North-South downward gradient in England. ${ }^{1}$ The evidence concerning carcinogenicity is becoming clearer - between 4 and $6 \%$ of new cancers in the country each year are caused by alcohol; for breast cancer this risk pertains even among those classified as light drinkers. ${ }^{2}$ Over the last 5 years, the number of attendances at emergency departments for acute alcohol poisoning (aka binge drinking) has doubled, and inpatient admissions for alcohol-related problems have increased by over $50 \%$ in the last 8 years. In England in 2013, approximately $18 \%$ of men and $13 \%$ of women drank at a level considered to be putting them at increased risk of harm, and 5\% and 3\% respectively drank at a level considered to be posing a high risk to their health. ${ }^{7}$ The yearly costs of alcohol-related illness to the NHS exceed $\mathfrak{£} 3.5$ billion ${ }^{4} \ldots$
There are many potential routes to reversing the recent trend in alcohol-related deaths in the UK. Some, like minimum pricing, appear stalled, even when a devolved government has clearly enunciated the potential gains of fewer deaths, fewer hospital admissions, less crime and substantial financial saving. ${ }^{8}$ Others, like stricter local alcohol licensing policies, have been shown to be associated with a reduction in alcohol-related hospital admissions. ${ }^{9}$ Considering that hospital physicians are at the sharp end of alcohol-associated morbidity, what realistically can the individual physician do?

There are two local actions that can be reinforced. The first seems straightforward and cheap, though it takes that most precious of commodities - time. 'Brief interventions' of 5-15 minutes as the opportunity arises - summarised for example by the FRAMES principles (feedback, responsibility, advice, menu, empathy and self-efficacy) covering potential harm of continuing to drink and the benefits of changing, exploring barriers to change, suggestion of practical strategies and goals - have in most, though not all, studies produced a significant reduction in drinking when assessed after intervals of a year or more. ${ }^{10,11}$ In general practice the cost of providing 5 minutes of brief advice has been estimated at $\mathfrak{1} 12$ when delivered by a nurse and $£ 24$ by a GP. Interestingly, in primary care in the UK, over $50 \%$ of patients could recall a conversation about their smoking, but fewer than $7 \%$ of risky drinkers could recall a conversation about their drinking. ${ }^{12}$ Is provision of brief advice to appropriate patients something that could be added to a checklist on ward rounds?

Second, a figure of $73 \%$ is quoted for the proportion of NHS trusts that have some sort of alcohol service ${ }^{4}$ but the details thereof are unclear and far from uniform. Public Health England and the National Institute for Health and Care Excellence have produced guidance on specialist alcohol services operating within hospital settings. ${ }^{12,13}$ It may be argued that the implications of having, or not having, adequate alcohol services are so far-reaching that oversight of this should be made a responsibility at trust board level; meanwhile

$\begin{array}{ll}\text { Members of the editorial board } \\ \text { Prof Humphrey Hodgson } & \text { Dr Cordelia Coltart } \\ \text { Editor-in-chief } & \text { International editor } \\ \text { Dr Paul Grant } & \text { Cono Ariti } \\ \text { Editorial registrar } & \text { Statistical editor }\end{array}$

Dr Na'eem Ahmed Paul Belcher Dr Rodger Charlton Dr Tahseen Chowdhury Nick Cork

Dr Kate Evans Prof Brian Hurwitz

Dr Angela King
Prof Philip MacCarthy Prof Martin McKee Dr Mehool Patel Dr Gerrard Phillips Dr Roby Rakhit Prof Philip Smith Dr Kevin Stewart Prof Cameron Swift 
any hospital doctor who feels their local service is inadequate could press the issue with their local management.

\section{References}

1 Office for National Statistics. Alcohol-related deaths in the UK, registered in 2014. Newport: ONS, 2016. Available online at www.ons. gov.uk/ons/rel/subnational-health4/alcohol-related-deaths-in-theunited-kingdom/2014/stb.html [Accessed 4 February 2016].

2 Committee on Carcinogenicity. Committee on Carcinogenicity of Chemicals in Food, Consumer Products and the Environment (COC) Statement 2015/S2 Statement on consumption of alcoholic beverages and risk of cancer. London: PHE, 2016. Available online at www. gov.uk/government/groups/committee-on-carcinogenicity-ofchemicals-in-food-consumer-products-and-the-environment-coc [Accessed 4 February 2016].

3 Department of Health. How to keep health risks from drinking alcohol to a low level: public consultation on proposed new guidelines. London: DoH, 2016. Available online at www.gov.uk/government/ consultations/health-risks-from-alcohol-new-guidelines [Accessed 4 February 2016].

4 Currie C, Davies A, Blunt I, Ariti C, Bardsley M. Alcohol-specific activity in hospitals in England. London: The Nuffield Trust, 2015. Available online at www.nuffieldtrust.org.uk/publications/alcoholspecific-activity-hospitals-england [Accessed 4 February 2016].

5 TheyWorkForYou. Second Reading - Road Traffic Act 1988 (Alcohol Limits) (Amendment) Bill [HL] - in the House of Lords at 10:56 am on 29th January 2016. Available online at www.theyworkforyou. com/lords/?id=2016-01-29a.1533.2\&s=rural [Accessed 4 February 2016].

6 Carrell S. Minimum alcohol price in Scotland breaches EU law, court rules. The Guardian, 23 December 2015. Available online at http://www.theguardian.com/society/2015/dec/23/minimumalcohol-price-in-scotland-could-breach-eu-law-court-rules [Accessed 4 February 2016].
7 Health \& Social Care Information Centre. Statistics on Alcohol, England 2015. Leeds: HSCIC, 2015. Available online at www.hscic. gov.uk/catalogue/PUB17712/alc-eng-2015-rep.pdf [Accessed 4 February 2016].

8 The Scottish Government. Minimum pricing. Edinburgh: The Scottish Government, 2015. Available online at www.gov.scot/ Topics/Health/Services/Alcohol/minimum-pricing [Accessed 4 February 2016].

9 de Vocht F, Heron J, Angus C et al. Measurable effects of local alcohol licensing policies on population health in England. J Epidemiol Community Health 2015, epub ahead of print.

10 NICE Pathways. Brief advice for adults who are attending a service. London: NICE, 2016. Available online at http://pathways.nice.org. $\mathrm{uk} /$ pathways/alcohol-use-disorders\#path=view\%3A/pathways/ alcohol-use-disorders/brief-interventions-for-alcohol-usedisorders.xml\&content=view-node\%3Anodes-brief-advice-foradults-who-are-attending-a-service [Accessed 4 February 2016].

11 National Institute for Health and Care Excellence. Alcohol-use disorders: prevention. PH24. London: NICE, 2010. Available online at www.nice.org.uk/guidance/ph24 [Accessed 4 February 2016].

12 Brown J, West R, Angus C et al. Comparison of brief interventions in primary care on smoking and excessive alcohol consumption in England. Br J Gen Pract 2016;66:e1-9.

13 Public Health England. Hospital alcohol services example core minimum dataset. London: PHE, 2015. Available online at www.alcohollearningcentre.org.uk/library/ Hospitalalcoholservicesexamplecoreminimum_dataset_2015.pdf [Accessed 4 February 2016].

14 National Institute for Health and Care Excellence. Services for the identification and treatment of hazardous drinking, harmful drinking and alcohol dependence in children, young people and adults. CMG38. London: NICE, 2011. Available online at www.nice.org.uk/ guidance/cmg38 [Accessed 4 February 2016].

Humphrey Hodgson 